\title{
Australian Precipitation Recycling and Evaporative Source Regions $\mathfrak{a}^{\circ}$
}

\author{
C. M. Holgate \\ Fenner School of Environment and Society, Australian National University, Canberra, Australian Capital Territory, and \\ ARC Centre of Excellence for Climate System Science, University of New South Wales, Sydney, New South Wales, Australia

\section{J. P. EVANS} \\ ARC Centre of Excellence for Climate Extremes, and Climate Change Research Centre, School of Biological, Earth and \\ Environmental Sciences, University of New South Wales, Sydney, New South Wales, Australia \\ A. I. J. M. VAN DIJK \\ Fenner School of Environment and Society, Australian National University, Canberra, Australian Capital Territory, Australia

\section{A. J. PITMAN} \\ ARC Centre of Excellence for Climate Extremes, and Climate Change Research Centre, School of Biological, Earth and \\ Environmental Sciences, University of New South Wales, Sydney, New South Wales, Australia \\ G. Di VIRGILIO \\ Climate Change Research Centre, School of Biological, Earth and Environmental Sciences, University of New South Wales, \\ Sydney, New South Wales, Australia
}

(Manuscript received 15 December 2019, in final form 12 July 2020)

\begin{abstract}
The relative importance of atmospheric advection and local land-atmosphere coupling to Australian precipitation is uncertain. Identifying the evaporative source regions and level of precipitation recycling can help quantify the importance of local and remote marine and terrestrial moisture to precipitation within the different hydroclimates across Australia. Using a three-dimensional Lagrangian back-trajectory approach, moisture from precipitation events across Australia during 1979-2013 was tracked to determine the source of moisture (the evaporative origin) and level of precipitation recycling. We show that source regions vary markedly for precipitation falling in different regions. Advected marine moisture was relatively more important than terrestrial contributions for precipitation in all regions and seasons. For Australia as a whole, contributions from precipitation recycling varied from $\sim 11 \%$ in winter up to $\sim 21 \%$ in summer. The strongest land-atmosphere coupling was in the northwest and southeast where recycled local land evapotranspiration accounted for an average of $9 \%$ of warm-season precipitation. Marine contributions to precipitation in the northwest of Australia increased in spring and, coupled with positive evaporation trends in the key source regions, suggest that the observed precipitation increase is the result of intensified evaporation in the Maritime Continent and Indian and Pacific Oceans. Less clear were the processes behind an observed shift in moisture contribution from winter to summer in southeastern Australia. Establishing the climatological source regions and the magnitude of moisture recycling enables future investigation of anomalous precipitation during extreme periods and provides further insight into the processes driving Australia's variable precipitation.
\end{abstract}

KEYWORDS: Atmosphere-land interaction; Climatology; Feedback; Water vapor; Semi-Lagrangian models

Supplemental information related to this paper is available at the Journals Online website: https://doi.org/10.1175/JCLI-D-190926.s1.

Corresponding author: Chiara Holgate, chiara.holgate@anu.edu.au 


\section{Introduction}

The origin of moisture for regional precipitation indicates the relative importance of local versus remote processes. Regions that receive a large portion of their moisture from local terrestrial sources are likely to experience stronger land-atmosphere coupling relative to regions where precipitation is typically derived from advected marine moisture (Eltahir and Bras 1996). In Australia, the relative importance of local terrestrial versus remote oceanic processes affecting precipitation is currently uncertain (Evans et al. 2011): Where does the moisture come from, and how strongly do landatmosphere coupling processes attenuate or amplify atmospheric moisture to impact local precipitation depth and timing?

Identifying the evaporative source regions that supply moisture for precipitation can reveal important aspects of a region's hydroclimatology. Knowing the long-term average source regions provides insight into the drivers of precipitation during anomalously dry or wet periods (Dirmeyer et al. 2014). In the case of drought, for example, identifying the long-term average source regions can help reveal whether the low precipitation was due to a reduction in source evaporation, anomalous atmospheric circulation (i.e., the moisture was generated but transported elsewhere), a lack of local precipitation-generating mechanisms, land-atmosphere coupling, or a combination of factors. Second, if a region's precipitation is dependent on precipitation recycling over land, then the land surface state and how it is coupled to the atmosphere becomes important to any explanation of precipitation anomalies. Establishment of the terrestrial sources also allows the identification of areas where distant land-use change may affect local precipitation (van der Ent et al. 2010). Similarly, identifying the marine sources allows investigation of how future changes in sea surface temperatures (SSTs) and atmospheric circulation influence local precipitation changes.

Dirmeyer et al. (2009) estimated the annual average source regions supplying moisture for precipitation to most countries, including Australia, between 1979 and 2003. They found Australian precipitation mainly to originate as moisture from marine evaporation, particularly along the coastlines in all but the southeast corner of Australia, and to originate via terrestrial moisture in northern and eastern Australia. Other studies have explored the source regions for precipitation over individual regions (Stohl and James 2005; Sharmila and Hendon 2020) and in selected wet and dry years (Miralles et al. 2016). Other studies have shed light on where moisture evaporated over predefined ocean regions falls as precipitation over Australia (van der Ent and Savenije 2013; Gimeno et al. 2012). How source regions vary for precipitation falling in each part of the continent, and how sources vary between seasons and years, has not been previously examined. A more detailed analysis of source regions for each part of the continent, and how these regions vary temporally, is required to examine the interplay between large-scale processes and local coupling mechanisms that attenuate or amplify precipitation within the different hydroclimatic regimes across Australia. Regions need to be studied individually if important coupling mechanisms operating during average versus anomalous periods are to be revealed.

Precipitation recycling is one measure of landatmosphere coupling strength. The precipitation recycling ratio is the proportion of a region's precipitation that is derived from evapotranspiration in that same region. High recycling levels may be indicative of strong, positive land-atmosphere coupling (Brubaker et al. 1993), whereby a decrease in soil moisture may lead to a decrease in local evapotranspiration and precipitation (Zhang et al. 2008), potentially contributing to the persistence of droughts (Brubaker et al. 1993). Previous estimates indicate that precipitation recycling in Australia may vary from as much as $38 \%$ for the whole continent (Dirmeyer et al. 2009) to $5 \%$ at a scale of $10^{5} \mathrm{~km}^{2}$ (Dirmeyer and Brubaker 2007; van der Ent and Savenije 2011). Given these uncertainties, a long-term dataset of evaporative source regions and precipitation recycling for each part of Australia could help establish the relative importance of local versus remote processes and the strength of coupling processes across periods of average and anomalous precipitation.

We aim to develop such a long-term dataset. Our objectives are 1) to establish a multidecadal time series of daily evaporative source regions and precipitation recycling across the Australian continent and for its 13 major hydrological basins using the Lagrangian backtrajectory method based on Dirmeyer and Brubaker $(1999,2007) ; 2)$ to define interannual and intraseasonal variability of evaporative source regions and precipitation recycling for each part of Australia; and 3) to determine where recycling plays a significant role in the generation of regional precipitation, and when and where large-scale processes dominate precipitation generation through moisture advection. To achieve these objectives, we investigated the period 1979-2013, covering periods of average precipitation and severe drought and flood, and extend the analysis of Dirmeyer et al. (2009) to include the Millennium Drought (2001-09) and a subsequent wet period (2010-11). 


\section{Data and methods}

\section{a. Back-trajectory model}

We tracked atmospheric water (vapor, liquid, and solid) from all precipitation events exceeding $2 \mathrm{~mm} \mathrm{day}^{-1}$ backward in time and space to identify their moisture origin using a Lagrangian back-trajectory model with explicit moisture accounting based on Dirmeyer and Brubaker (1999). Precipitation falling anywhere on the Australian continent between 1979 and 2013 was tracked.

For each day that precipitation occurred at grid cell $i$, air parcels were launched at a rate proportional to the rate of precipitation. Parcels were released from a random, total-precipitable-water-weighted height in the atmosphere, assuming the vertical distribution of precipitable water indicates where the precipitation forms. Each parcel $k$, treated as a passive water vapor tracer, was advected through the atmosphere using threedimensional (3D) wind fields and the fully implicit technique of Merrill et al. (1986):

$$
\begin{aligned}
& x^{n-1}=x^{n}+\frac{\Delta t u^{n}+\Delta t u^{n-1}}{2} \text { and } \\
& y^{n-1}=y^{n}+\frac{\Delta t v^{n}+\Delta t v^{n-1}}{2},
\end{aligned}
$$

where $x$ and $y$ (both in meters) are the grid coordinates along the trajectory; $u$ and $v$ (both in meters per second) are the zonal and meridional wind components, respectively; $\Delta t(\mathrm{~s})$ is the time interval; and $n(\mathrm{~s})$ is the time step. Height displacement of the parcel was determined with the vertical wind component.

At each 10-min time interval of the back trajectory, part of the parcel's water vapor was assumed to have come from evaporation of the grid cell $x, y$ underlying the parcel at that point in its trajectory, assuming the evaporation mixes well throughout the entire atmospheric column during the time step, and that evaporation was the only source of moisture for the parcels. Moisture was added to parcel $k$ according to

$$
C_{i, k}(x, y, t)=\frac{E(x, y, t)}{\mathrm{TPW}_{i}}
$$

where $C_{i, k}$ (fraction) is the contribution of moisture at grid cell $x, y$ at time $t$ to parcel $k, E(\mathrm{~m})$ is the estimated evaporation at grid cell $x, y$ at time $t$, and $\mathrm{TPW}_{i}(\mathrm{~m})$ is the total precipitable water above original grid cell $i$ at the time of the precipitation event (Dirmeyer and Brubaker 1999).

For each $0.5^{\circ}$ grid cell across Australia, up to 100 parcels were released every day, dependent on the proportion of time it rained during the day; at least one parcel per 10-min simulation time step was released for cells where it rained. Parcels were released from the location of each precipitation event and tracked backward until all of the precipitable water for that event had been accounted for, or until the maximum backtrajectory time (set at 30 days) had been reached, or until the parcel reached the boundary of the model domain. The total evaporative contribution $E_{A}(x, y)$ of parcels $k-m$ over time $t$ to $t_{\max }$ across all grid cells $i-n$ within area $A$ where it rained is therefore

$$
E_{A}(x, y)=\sum_{i=1}^{n} \sum_{k=1}^{m} \sum_{t=0}^{t_{\max }} C_{i, k}(x, y, t) .
$$

When summed over all grid points in the domain, the $E_{A}(x, y)$ equals $P_{A}$, the total precipitation in area $A$ (Dirmeyer and Brubaker 1999). This process was repeated until all precipitable water from all precipitation events across Australia during 1979-2013 had been accounted for. This yielded the source regions for Australian precipitation; that is, a daily map of evaporated water vapor that contributed to precipitation over the Australian continent each day during the 35-yr time frame. The $3 \mathrm{D}$ distribution of $E_{A}(x, y)$ was then partitioned to obtain the evaporative source regions for precipitation falling in each of Australia's major hydrological basins. Basin boundaries (Fig. 1) were the major topographic drainage divisions derived from the Australian Hydrological Geospatial Fabric (Bureau of Meteorology 2012).

This method makes some assumptions that may impact the accuracy of the identified moisture source regions, including that evaporative water is well mixed vertically at the time scale of the back-trajectory model and that the vertical distribution of precipitable water indicates where rain formation occurs vertically. Although testing of these assumptions is beyond the scope of the current study, past studies that addressed these uncertainties indicate that they are likely to have only small influences in our case (Goessling and Reick 2013; see the Text S1 section in the online supplemental material).

\section{b. Precipitation recycling}

The 3D time series of evaporative origin was used to determine the precipitation recycling ratio for each hydrological basin, where the recycling ratio $\rho$ is defined as the proportion of basin $A$ precipitation that originated as evaporation from that same basin:

$$
\rho=\sum E_{A}(x, y) / P_{A} .
$$

Recycling ratios are dependent on spatial scale, since recycling necessarily increases from zero at a point, to $100 \%$ for the whole globe. Given this scale dependency, 


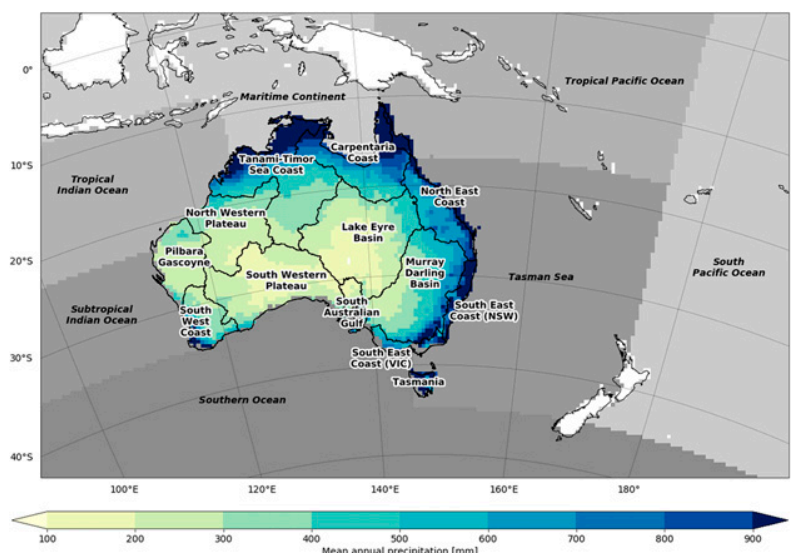

FIG. 1. Australian major hydrological basins and mean annual precipitation (Bureau of Meteorology 2010) set within the model domain. Ocean regions are delineated in grayscale (shades are arbitrary).

we also present scaled recycling ratios $\rho_{s}$ to allow a comparison between basins of different size and allow comparison with previous studies. Dirmeyer and Brubaker (2007) examined the relationship between recycling ratio and geographic area for different regions globally and empirically found a power law describing the data according to

$$
\rho_{s}=a A^{b},
$$

where $\rho_{s}$ is the scaled recycling ratio (\%), $A$ is the area $\left(\mathrm{km}^{2}\right)$, and $a$ and $b$ are fitting parameters. Dirmeyer and Brubaker (2007) found $b$ to vary little from an average 0.462 across the globe, suggesting that such a universal value of $b$ could be applied. Hence once the recycling ratio $\rho$ for a region of size $A$ has been calculated, the value of $a$ can be calculated by rearranging Eq. (5). A recycling ratio scaled to a new area can then be computed for the region $\left(\rho_{s}\right)$. In this study we find values for $a$ for each hydrological basin and then use $b=0.462$ and $A=10^{5} \mathrm{~km}^{2}$ to compute scaled recycling ratios $\rho_{s}$ for each basin.

\section{c. Back-trajectory forcing data}

The back-trajectory analysis was driven by time-varying $3 \mathrm{D}$ atmospheric fields of wind, temperature, precipitable water and pressure, and two-dimensional (2D) fields of precipitation and latent heat flux, produced by the ERAInterim-driven WRFv3.6.1 simulation. The simulation was performed over the Coordinated Regional Climate Downscaling Experiments (CORDEX)-Australasia domain at $\sim 50 \mathrm{~km}$ horizontal resolution and 30 vertical levels spaced closer together in the boundary layer. The model physics parameterizations included the Mellor-YamadaJanjić planetary boundary layer, Betts-Miller-Janjić cumulus, WRF double-moment 5-class cloud microphysics,
Rapid Radiative Transfer Model longwave radiation, Dudhia shortwave radiation, and the Noah land surface model. This simulation uses spectral nudging of winds and geopotential height above approximately $500 \mathrm{hPa}$ using ERA-Interim (Evans et al. 2013). This ensures that the synoptic-scale weather systems within the WRF simulation remain close to those in the reanalysis but has the advantage of conserving water, which the reanalysis does not do due to its assimilation of observations.

An ensemble of ERA-Interim driven simulations within the CORDEX-Australasia modeling framework was recently evaluated by Di Virgilio et al. (2019) for the period 1981-2010 and included the WRF configuration called UNSW-WRF360K. The simulation used in the present study is UNSW-WRF360K, but with additional spectral nudging of winds and geopotential. The spectrally nudged simulation (WRF360K-Nudged) was not included in Di Virgilio et al. (2019) but is evaluated here following the same evaluation method and is presented in the online supplemental material in comparison with other CORDEX-Australasia models defined in $\mathrm{Di}$ Virgilio et al. (2019). The ensemble of regional models was evaluated against observations contained within the Australian Gridded Climate Dataset (AGCD; Jones et al. 2009) on an annual and seasonal basis. WRFsimulated precipitation variability and trends have also been extensively evaluated (Cortés-Hernández et al. 2016; Fita et al. 2017; Olson et al. 2016; Evans et al. 2017) and performed well overall.

In terms of minimum and maximum temperature, the mean bias for UNSW-WRF360K-Nudged was smaller than the ensemble mean for all seasons of the year, with correlation coefficients $r$ ranging between 0.92 and 0.98 (Table $\mathrm{S} 1$ in the online supplemental material). Maximum temperature (annual mean bias $-0.64 \mathrm{~K}$; Table S2 in the online supplemental material) tended to be underestimated in eastern Australia (Fig. S1 in the online supplemental material), especially in winter ( $\sim-3 \mathrm{~K}$; Fig. S2 in the online supplemental material) and was overestimated in parts of western and northern Australia in summer ( $\sim 2 \mathrm{~K}$; Fig. S3 in the online supplemental material). Annual mean bias in minimum temperature was small $(0.24 \mathrm{~K}$; Table S2 and Fig. S4 in the online supplemental material), with winter minimum temperatures underestimated $(\sim-2 \mathrm{~K})$ in the west and parts of the east, with some overestimation occurring in eastern and northern Australia ( $\sim 2 \mathrm{~K}$; Fig. S5 in the online supplemental material). In summer, minimum temperatures were overestimated in central and southeastern Australia $(\sim 2 \mathrm{~K})$ and underestimated in the southwest and northeast $(\sim-1.5 \mathrm{~K}$; Fig. $\mathrm{S} 6$ in the online supplemental material). 
UNSW-WRF360K-Nudged estimated precipitation well overall (annual $r=0.88$; Table S1) and better than the equivalent nonnudged simulation (UNSWWRF360K) in all seasons. UNSW-WRF360K-Nudged underestimated annual precipitation in coastal regions (mean bias $-7.6 \mathrm{~mm}$ month $^{-1}$; Table S2 and Fig. S7 in the online supplemental material), but had the lowest proportion of land with annual mean bias exceeding $10 \mathrm{~mm} \mathrm{month}^{-1}$ ( $1 \%$ as compared with $24 \%$ ensemble mean; Table S3 in the online supplemental material). In winter UNSW-WRF360K-Nudged estimated precipitation well $[r=0.90$ (Table S1) and mean bias over Australia of $-4.9 \mathrm{~mm}$ month $^{-1}$ (Table S2)] but was positively biased along the southern coastline (up to $\sim 40 \mathrm{~mm} \mathrm{month}^{-1}$; Fig. S8 in the online supplemental material). Summer precipitation was also well simulated $[r=0.93$ (Table S1) and mean bias over Australia of $-16.6 \mathrm{~mm}$ month $^{-1}$ (Table S2)] but overestimated precipitation in the monsoonal north (up to $\sim 40 \mathrm{~mm}$ month ${ }^{-1}$; Fig. S9 in the online supplemental material). In both seasons UNSW-WRF360K-Nudged still achieved a much smaller proportion of land with mean bias exceeding $10 \mathrm{~mm}$ month $^{-1}$ ( $2 \%$ and $0.8 \%$ in summer and winter, respectively; Table S3) relative to the ensemble mean $(24 \%$ and $19 \%$ in summer and winter, respectively; Table S3).

UNSW-WRF360K-Nudged evapotranspiration estimates were compared to the Derived Optimal Linear Combination Evapotranspiration (DOLCE), version 2 (Hobeichi et al. 2018, 2020), a hybrid of 11 global evapotranspiration datasets. Hobeichi et al. (2018) showed the hybrid dataset outperformed its constituent products when compared to global flux tower measurements. UNSW-WRF360K-Nudged estimated evapotranspiration well overall (annual $r=0.72$ ), but relative to DOLCE tended to underestimate $\left(\sim-0.5 \mathrm{~mm} \mathrm{day}^{-1}\right)$ values in the interior north and east of Australia in both summer and winter, with bias reaching $\sim-1.3 \mathrm{~mm} \mathrm{day}^{-1}$ along the mountainous region of southeast Australia in summer (Fig. S10 in the online supplemental material). Evapotranspiration was overestimated along the coastlines $\left(>0.5 \mathrm{~mm} \mathrm{day}^{-1}\right.$; Fig. S10) in summer, likely a reflection of large ocean-land evaporation differences and differences in dataset land-water masks at the coastlines. The interannual variability was very similar to that of DOLCE for the study period, with both datasets displaying an $11 \%$ coefficient of variation. Neither dataset showed statistically significant $(p<0.05)$ trends in annual continentwide estimates during the study period.

Overall, the strong performance of the WRF simulation compared to observed temperature, precipitation and evapotranspiration, and ability of the model to conserve water (unlike reanalysis products) makes the simulation ideal for driving the back-trajectory analysis over Australia.

\section{Results}

\section{a. Evaporative source regions}

Moisture source regions showed strong seasonal shifts in evaporative contribution $\left(E_{A}\right)$ and spatial domain. In summer (Fig. 2a), moisture for Australia's precipitation was principally sourced from the Maritime Continent, tropical Indian Ocean, tropical Pacific Ocean, and Tasman Sea and from the subtropical Indian and Southern Oceans close to the Australian continent. Terrestrial contributions from Australia were at their peak in summer and were highest in the northern and eastern parts of the continent. During summer, some terrestrial moisture $(1.1 \%)$ was also sourced from Indonesia, East Timor, Papua New Guinea, Solomon Islands, Vanuatu, and New Caledonia. The stronger moisture contribution to the north is due to the summerdominant rainfall climate of northern Australia during the monsoon season. In autumn, moisture contribution from the north declined sharply (Fig. 2b), and the most important source region became the tropical Pacific Ocean and Tasman Sea. In winter, the terrestrial contribution was negligible except for parts of eastern and southwestern Australia (Fig. 2d). Marine source regions contracted southward in line with the northward progression of the subtropical ridge, where frontal systems extend farther into southern Australia, and the northward progression of the monsoon trough, as northern Australia moves into its dry season. In spring, the marine source regions expanded northward once again, and the terrestrial contribution increased across most of the continent, most strongly in the southeast (Fig. 2c) with the Tasman Sea the dominant source. In all seasons the proportion of moisture sourced from outside the model domain tended to be less than $7 \%$ of the total contributed to Australian precipitation (Figs. 2e,f; Table S4 in the online supplemental material).

Figure 3 highlights the summer source regions for selected basins in the northwest, southeast and southwest of Australia. Source regions for all basins and seasons are shown in Figs. S11a and S11b in the online supplemental material. Summer precipitation in the northwest as defined by the Tanami-Timor Sea Coast basin (Fig. 3a) was dominated by moisture from the tropical Indian Ocean, Maritime Continent, and the subtropical Indian and Southern Oceans close to Australia. Some moisture was also sourced from the tropical Pacific Ocean, extending east of New Caledonia in summer. In addition to marine moisture, the Tanami-Timor Sea Coast 

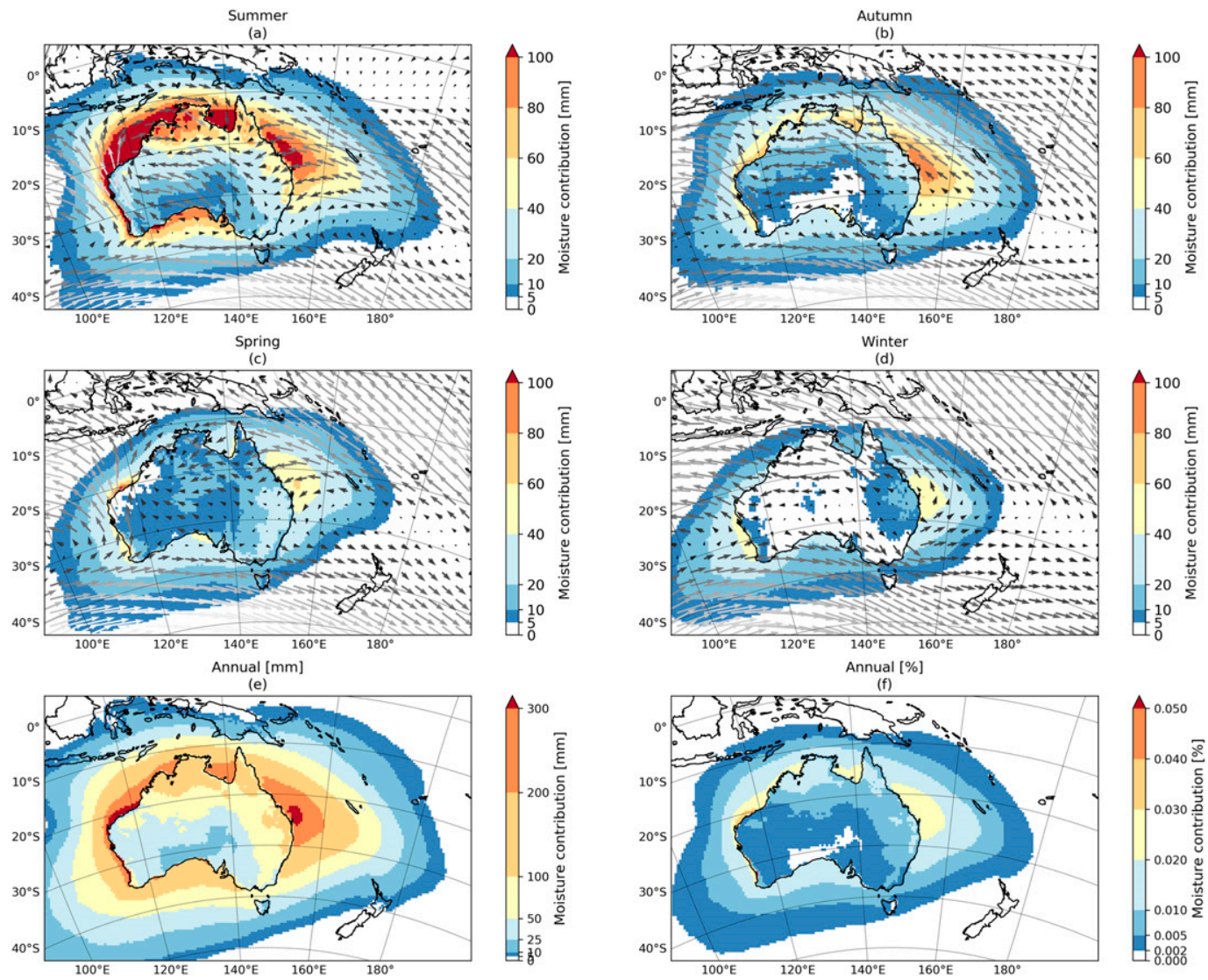

FIG. 2. Mean moisture contribution to Australian precipitation in (a)-(d) each season ( $\mathrm{mm}$ ), with mean climatological low-level wind vectors, (e) annually (mm), and (f) as a percent of annual Australian precipitation (\%). Note the nonlinear color scale.

also received significant terrestrial contributions from the basin itself (see section 3b). Total moisture contribution reduced strongly in autumn; was minimal in the dry season and increased again in spring (Fig. S11a). Moisture sourced from outside the model domain was low, reaching a maximum of $3.3 \%$ in summer through the western model boundary (Table S4).

Summer precipitation in the southeast as defined by the Murray-Darling Basin (MDB) was primarily sourced from the Tasman Sea, Southern Ocean, and the land within the basin. Secondary contributions were made from the other land and ocean regions, with up to $7.7 \%$ of moisture sourced from beyond the southern model boundary (Fig. 3b; Table S4). Unlike the Tanami-Timor Sea Coast, the overall source region for the MDB experienced relatively minor seasonal shifts in spatial contribution (Fig. S11b).

The small moisture contribution to the South West Coast (Fig. 3c) reflects the relatively low seasonal (and annual) precipitation of this comparatively smaller basin. Moisture contribution was constrained to the subtropical Indian and Southern Oceans. Up to $8 \%$ of total moisture was sourced from beyond the southern model boundary in summer, reaching $12.7 \%$ through the western boundary in winter (Table S4).

\section{b. Terrestrial and marine contributions}

The marine moisture contribution dominated yearround for all basins (Fig. 4). The continent typically received a minimum of $77 \%$ of moisture from marine sources in summer and a maximum of $89 \%$ in winter (Fig. 4). Terrestrial contributions were greatest in the northern basins compared to the south in summer and autumn and tended to be similar in winter and spring. For all basins, terrestrial contributions peaked in spring and summer.

In summer, north-northwestern basins (North Western Plateau, Tanami-Timor Sea Coast, Carpentaria Coast, and North East Coast) typically received $23 \%$ of moisture from terrestrial sources, whereas southeastern basins (MDB; South East Coast, New South Wales; South East Coast, Victoria; Tasmania) received $17 \%$ (Fig. 4). The same north-northwestern basins received $12 \%$ of moisture from the terrestrial sources during winter (northern dry season), 

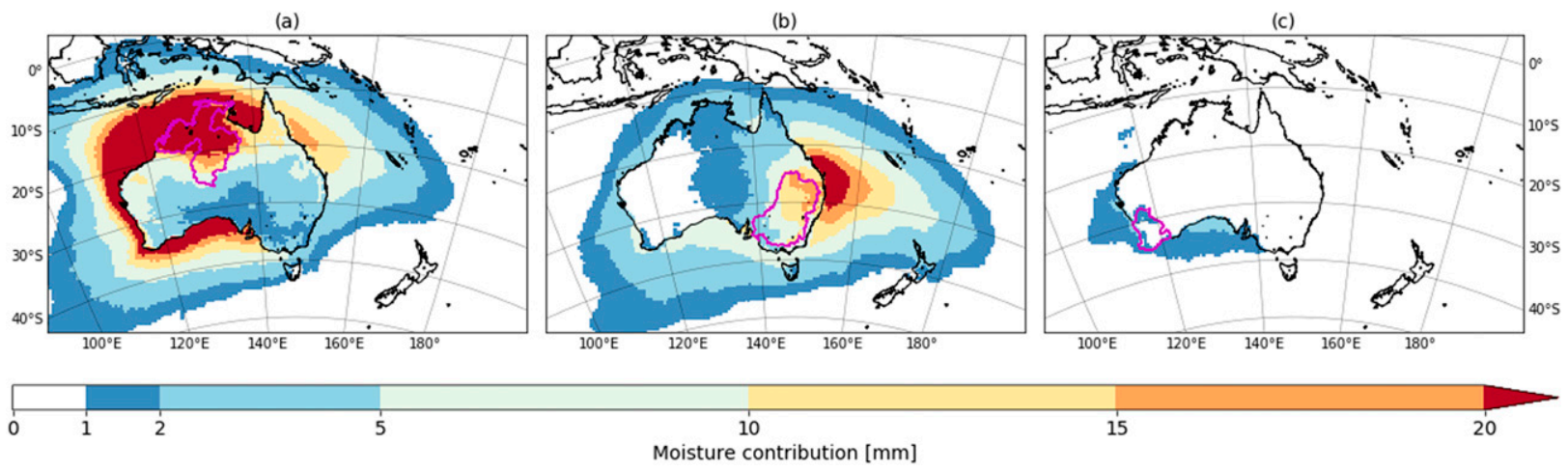

FIG. 3. Mean summer moisture contribution (mm) to precipitation in (a) Tanami-Timor Sea Coast, (b) Murray-Darling Basin, and (c) South West Coast.

compared to the $11 \%$ received by southeastern basins. In spring, the southeastern basins received slightly more moisture from the terrestrial sources $(18 \%)$ relative to north-northwestern basins (17\%; Fig. 4).

\section{c. Interannual variability}

Interannual variability in terrestrial moisture contribution to Australian precipitation was high for all basins.
Figure 5 shows the mean annual contributions from marine and terrestrial sources, with associated coefficients of variation $(\mathrm{CV})$. The $\mathrm{CV}$ is the standard deviation of moisture contributed to the basin normalized by its mean to allow for a direct relative comparison between basins. In a relative sense, interannual moisture contribution from local and nonlocal terrestrial sources (CV 18\%) varied more than marine contribution (CV 3\%).
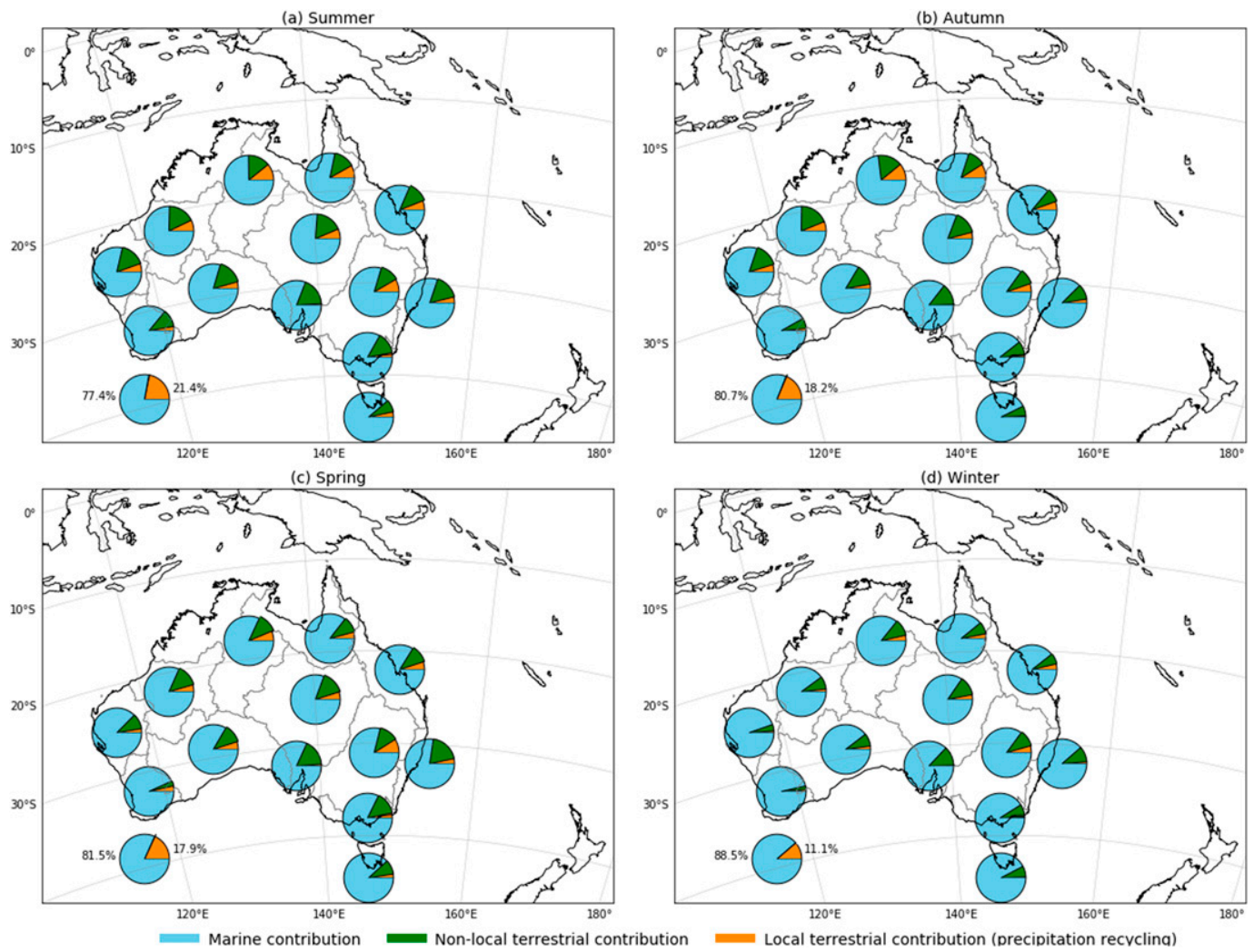

FIG. 4. Mean seasonal contributions to precipitation by basin. Contributions to Australia-wide precipitation are provided in the bottom-left corner of each panel (remaining proportions represent moisture contributed from other countries). 


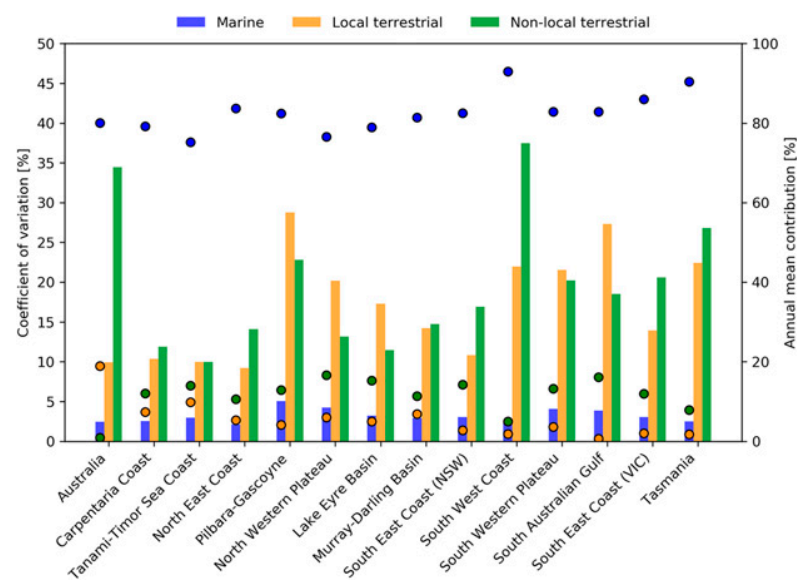

FIG. 5. Interannual variability in marine and terrestrial contribution to precipitation, presented as the coefficient of variation (bars; left axis) with annual mean contribution (dots; right axis).

The annual marine contribution to North East Coast rainfall was the least variable (CV 2.1\%; Fig. 5), whereas Pilbara-Gascoyne, located in the westernmost part of Australia (Fig. 1), experienced the largest interannual variability (CV 5\%; Fig. 5). The North East Coast and Pilbara-Gascoyne also experienced the lowest $(\mathrm{CV}$ $9.2 \%$; Fig. 5) and highest (CV 28.8\%; Fig. 5) interannual variability in local terrestrial contribution (i.e., precipitation recycling, see section $3 \mathrm{~d}$ ). The annual nonlocal terrestrial contribution to the Tanami-Timor Sea Coast was the least variable (CV 10\%; Fig. 5), and the South West Coast was most variable (CV 37.5\%; Fig. 5).

Figure 6 decomposes the interannual variability in the marine contribution by ocean region, with regions defined in Fig. 1. It shows the contribution each ocean region makes to the total interannual variability in moisture contributed to Australia and its subbasins. That is, for each basin, we divide the variance in contribution from each ocean region $(\mathrm{mm})$ by the variance in the total marine contribution ( $\mathrm{mm})$. As expected, Fig. 6 shows greater variability in the southern basins compared to the tropical north. In all seasons the Southern Ocean contributed the most to variability of the southern basins (e.g., $>50 \%$ for Tasmania in all seasons), as well as the Tasman Sea to most basins and especially those on the east coast (e.g., $>50 \%$ for South East Coast, New South Wales, in all seasons). The tropical Indian Ocean contributed to variability in the northern basins during the wet season, but, like the Maritime Continent, was very stable in the dry season. The subtropical Indian Ocean contributed to variability of the southwestern basins in all seasons and western basins in winter. The South Pacific Ocean, tropical Pacific Ocean, and Maritime Continent contributed the least to interannual variability across Australia. Like
Fig. 5, Fig. 6 shows North East Coast experienced the smallest variability in its source regions.

\section{d. Precipitation recycling}

Figure 7 shows the annual cycle of precipitation recycling $(\rho)$ for Australia and each basin. On average $19 \%$ of moisture was recycled to contribute to further precipitation across Australia (Fig. 7a). The northern tropical basins (Carpentaria Coast and Tanami-Timor Sea Coast) recycled the largest amount of local moisture, recycling a maximum of $8.8 \%-11.4 \%$ of monthly precipitation ( $\rho$; Fig. 7 ). Apart from these, the MDB recycled more precipitation than any of the other basins in the east, south, northwest and northeast of Australia, recycling a maximum of $9.2 \%$, and $6.9 \%$ on average across the year ( $\rho$; Fig. $7 \mathrm{~h})$. The least amount of precipitation was recycled in the South Australian Gulf $(0.7 \%)$, Tasmania (1.7\%), and South West Coast (1.8\%; Fig. 7). Recycling in the northern basins peaked in March at the end of the wet season, as did the northwestern basins (Pilbara-Gascoyne and North Western Plateau). Recycling in the Lake Eyre Basin and the southern basins peaked between October and January. All southern basins recycled the least amount of precipitation in June. While the northern and northwestern basins experienced a minimum in June/July, the minimum recycling in the Carpentaria Coast was delayed until September, that is, at the very end of the dry season.

The scaled precipitation recycling estimates $\rho_{s}$ follow the same spatial pattern as the actual estimates, with highest recycling in the northern and southeast basins and lowest in the southwest (Fig. 7). Scaled recycling estimates are discussed and compared to previous studies in section $4 \mathrm{c}$.

\section{e. Trends}

Figure 8 shows temporal linear trends (1979-2013) in seasonal moisture contributions to precipitation in each basin, sourced from individual ocean regions (Fig. 1), the Australian landmass outside the basin and the land area within each basin. Trends are expressed as the change in seasonal moisture relative to the mean total seasonal moisture received by each basin (1979-2013). Trends in moisture contribution were frequently positive in spring and summer and negative in autumn and winter (Fig. 8). A positive trend in moisture contribution to northwestern basins is clear, especially in spring (Fig. 8d). Positive contributions occurred over all ocean areas, as well as the local and nonlocal terrestrial sources of moisture.

Trends in moisture contribution may be due to a change in source region evaporation, anomalous 

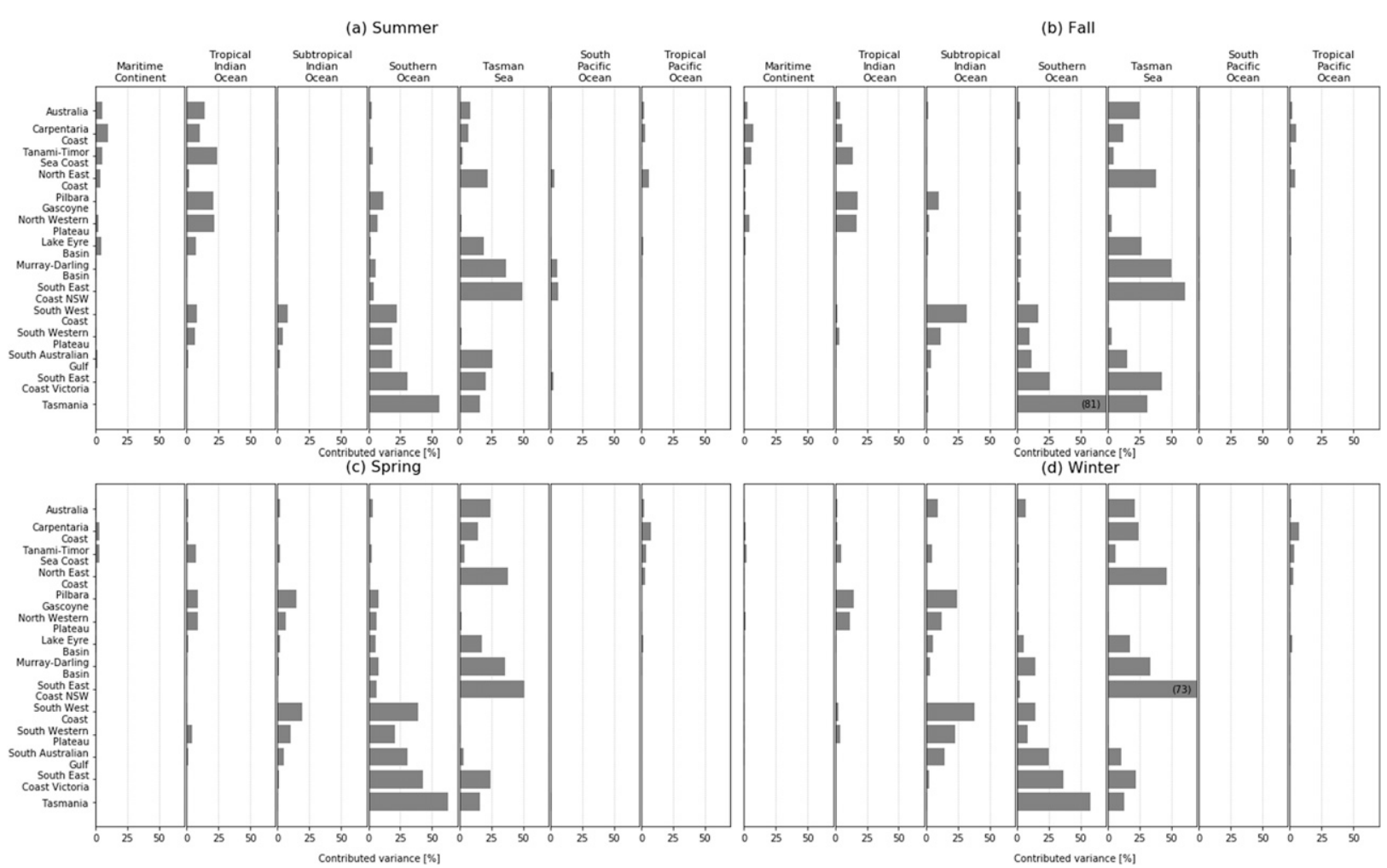

FIG. 6. Contribution to variance in moisture supplied to Australia and its subbasins by each ocean region. Values are provided in parentheses where the bar exceeds the axis limit.

atmospheric circulation (i.e., the moisture was generated but transported elsewhere), a lack of local precipitationgenerating mechanisms, land surface control on the atmosphere through coupling processes, or a combination of factors. Considering trends in evaporation of the source regions, we can, to first order, diagnose the processes driving the trends in moisture contribution. Positive spring trends in moisture contributed to the northwest coincides with positive trends in evaporation in the Maritime Continent, subtropical Indian Ocean, and tropical Pacific Ocean (Table S5 in the online supplemental material).

The South Pacific Ocean and the Tasman Sea showed significant positive trends in summer, with the highest trends in the MDB (Fig. 8a). In summer, the net upward trend in seasonal moisture contributed to the MDB amounted to $+0.94 \% \mathrm{yr}^{-1}$ (Fig. $8 \mathrm{a}$ ). In other words, $0.94 \%$ more moisture was available for summer precipitation in the MDB each year, compared to the summer average. Moisture declined by $-1.33 \% \mathrm{yr}^{-1}$ in autumn (Fig. 8b) and $-0.88 \% \mathrm{yr}^{-1}$ in winter (Fig. 8c), and increased in spring by $+0.35 \% \mathrm{yr}^{-1}$ (Fig. 8d), resulting in a net $-0.12 \% \mathrm{yr}^{-1}$ decline in moisture received by the MDB over the $35-\mathrm{yr}$ period. The positive trend in moisture contribution in summer along with the decrease in winter does not coincide with significant evaporation trends in the key source regions of the Tasman Sea and Southern Ocean (Table S5).

\section{Discussion}

\section{a. Source regions}

Our results show source regions vary markedly across the country. Along with notable terrestrial contributions in the north and southeast, moisture for precipitation in each basin was primarily derived from proximate marine sources. We note our marine evaporative source regions coincide with regions of high marine evaporation ( $\mathrm{Yu}$ 2007), especially in the Pacific Ocean.

Dirmeyer et al. (2009) estimated similar source regions for the Lake Eyre Basin (available at http://cola.gmu.edu/ $w c r /)$. Our estimate of the annual terrestrial contributions within Lake Eyre Basin and northeastern Australia was < $30 \mathrm{~mm} \mathrm{yr}^{-1}$ (Fig. S11a) as compared with Dirmeyer et al.'s (2009) estimate of $<50 \mathrm{~mm} \mathrm{yr}^{-1}$. Dirmeyer et al. (2009) also estimated a stronger annual terrestrial contribution from within the MDB (up to $\sim 100 \mathrm{~mm} \mathrm{yr}^{-1}$ as compared with our estimate of up to $\sim 50 \mathrm{~mm} \mathrm{yr}^{-1}$; Fig. S11b), and a stronger contribution from the Southern Ocean $\left(\sim 100 \mathrm{~mm} \mathrm{yr}^{-1}\right.$ as compared with $\sim 50 \mathrm{~mm} \mathrm{yr}^{-1}$ in our study; Fig. S11b). We note Stohl and James (2005) indicated the Tasman Sea to be the most important 


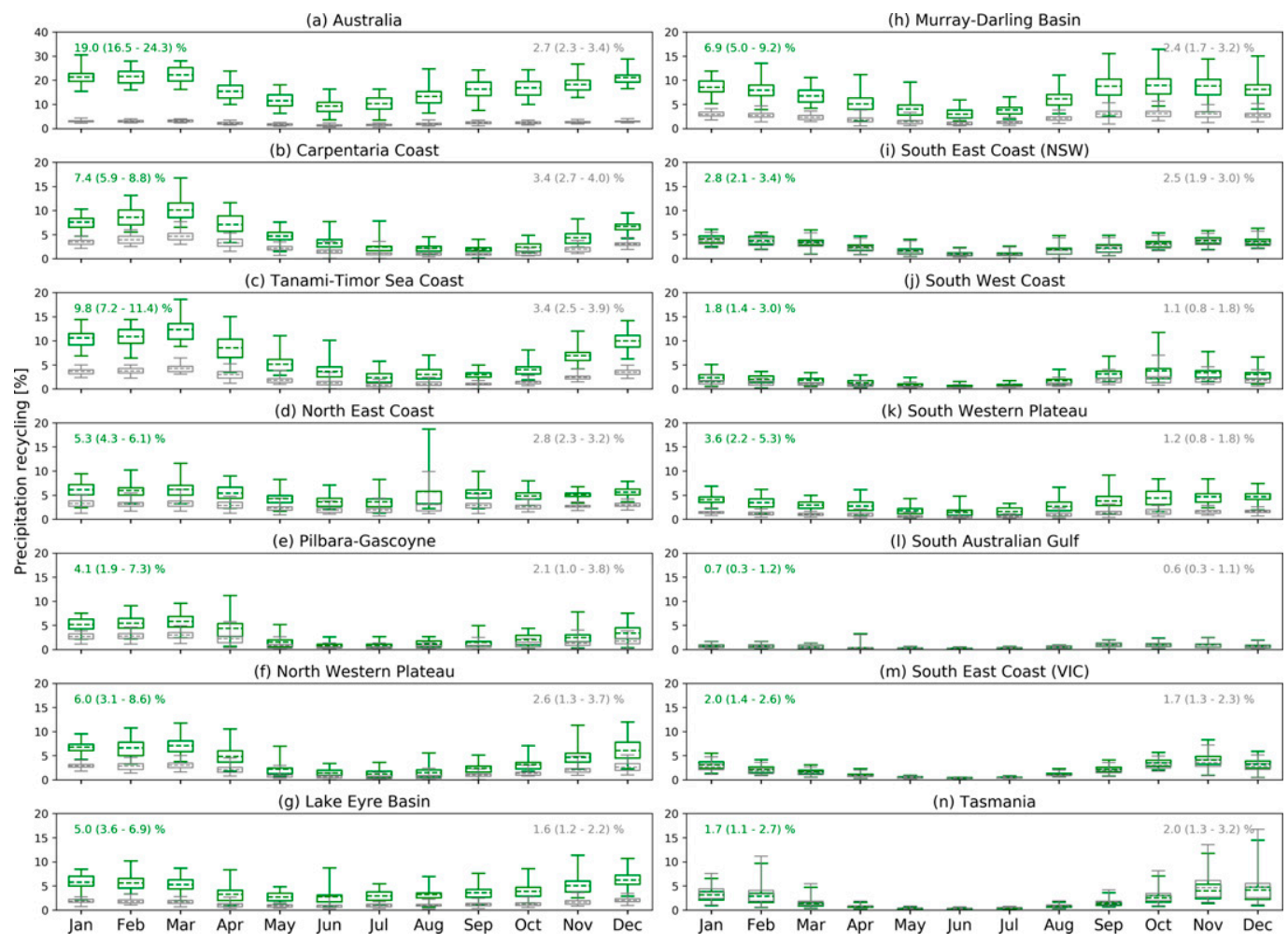

FIG. 7. Mean monthly precipitation recycling ( $\rho$; green) and scaled precipitation recycling ( $\rho_{s}$; gray). Annual mean and range are given in the top-left corner of each panel, and scaled estimates are given in the top-right corner. Note the different vertical scale for Australia in (a).

source of moisture to the MDB, contributing up to $\sim 100 \mathrm{~mm} \mathrm{yr}^{-1}$ of moisture to the basin, which is very similar to our results. However, Stohl and James (2005) estimated a greater contribution from the land surface in eastern Australia (up to $\sim 100 \mathrm{~mm} \mathrm{yr}^{-1}$ ) as compared with our estimate of $\sim 50 \mathrm{~mm} \mathrm{yr}^{-1}$ (Fig. S11b).

For the whole continent, the dominant annual source regions supplying moisture to precipitation across Australia match estimates by Dirmeyer et al. (2009). In both studies the main sources are proximate oceanic regions as well as the north and east of Australia. However, we estimate a greater contribution from the ocean and a smaller contribution from the land. This is demonstrated in the eastward and southward extension of the Pacific and Southern Oceans source regions relative to Dirmeyer et al. (2009). We estimate contributions up to $200 \mathrm{~mm} \mathrm{yr}^{-1}$ as far east as $\sim 170^{\circ} \mathrm{E}$ and as far south as $\sim 40^{\circ} \mathrm{S}$ (Fig. 2e), as compared with $\sim 155^{\circ} \mathrm{E}$ and $\sim 35^{\circ} \mathrm{S}$ by Dirmeyer et al. (2009). While both studies estimate that the greatest terrestrial contributions come from northern and eastern Australia, we estimate contributions up to $\sim 200 \mathrm{~mm} \mathrm{yr}^{-1}$ (Fig. 2e) as compared with $\sim 200-300 \mathrm{~mm} \mathrm{yr}^{-1}$ by Dirmeyer et al. (2009).

The importance of moisture from each ocean region varied for precipitation falling in different parts of Australia. Similar to our results, van der Ent and
Savenije (2013) estimated evaporation from the western tropical Pacific Ocean contributed to annual precipitation over most of the country except the southwestern and southeastern regions during 1990-2009. A similar result was also found by Gimeno et al. (2012), who found evaporation from the Coral Sea (covering part of the regions defined as the tropical Pacific Ocean and Tasman Sea in the present study) supplied moisture for precipitation over much of the continent in summer and northern and eastern Australia in winter, similar to the present study. Differences in source region estimates were expected due to different forcing, moisture tracking algorithms and time periods covered. We used a $0.5^{\circ} 3 \mathrm{D}$ Lagrangian back-tracking algorithm driven by an ERA-Interim-constrained regional simulation over 1979-2013. Dirmeyer et al. (2009) backtracked moisture at $1.9^{\circ}$ resolution using CMAP and NCEP data over 1979-2003. Stohl and James (2005) back-tracked moisture using the 3D Lagrangian flexible particle dispersion model (FLEXPART) at $1^{\circ}$ using data from ECMWF over 1999-2003. Gimeno et al. (2012) also used FLEXPART, but with data from ERA-40 over 1980-2000, and forward-tracked moisture from predefined ocean regions. Finally, van der Ent and Savenije (2013) used a $1.5^{\circ}$ vertically 
(a) Summer

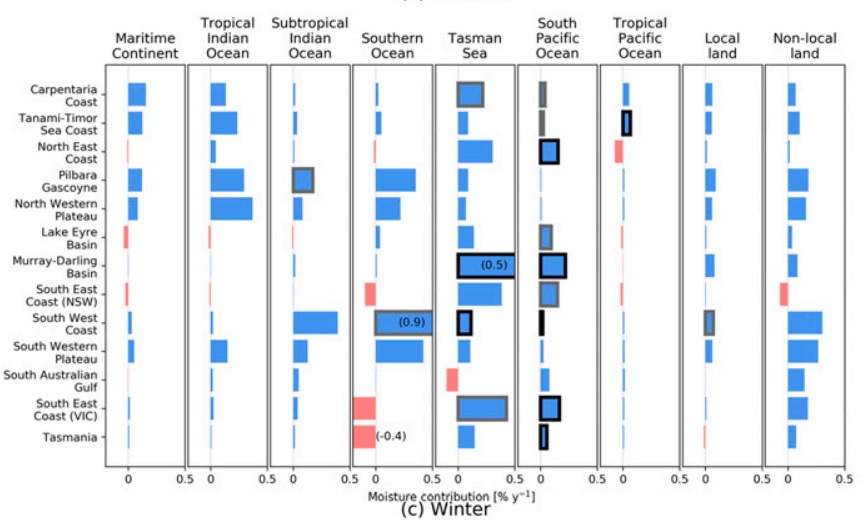

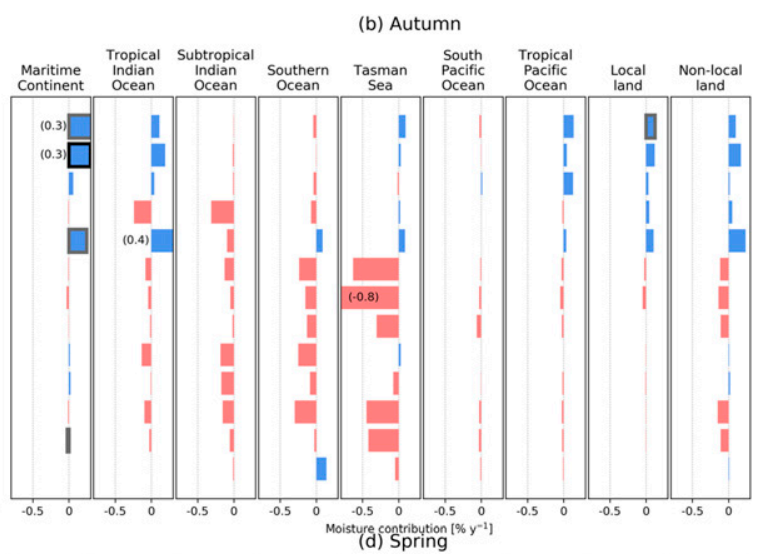

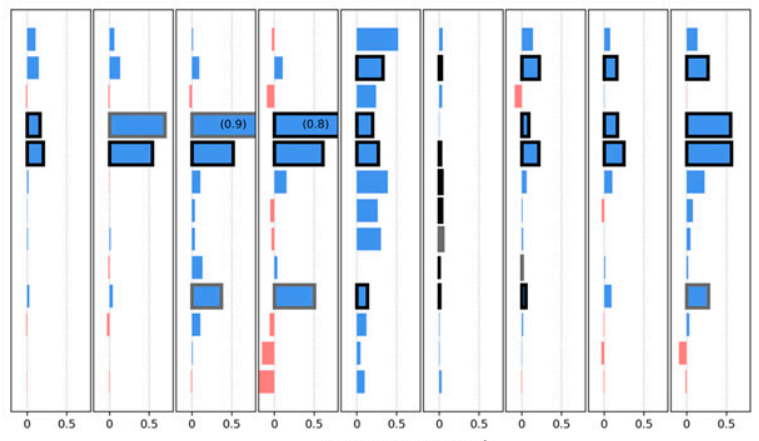

Moisture contribution $\left[\% y^{-1}\right]$

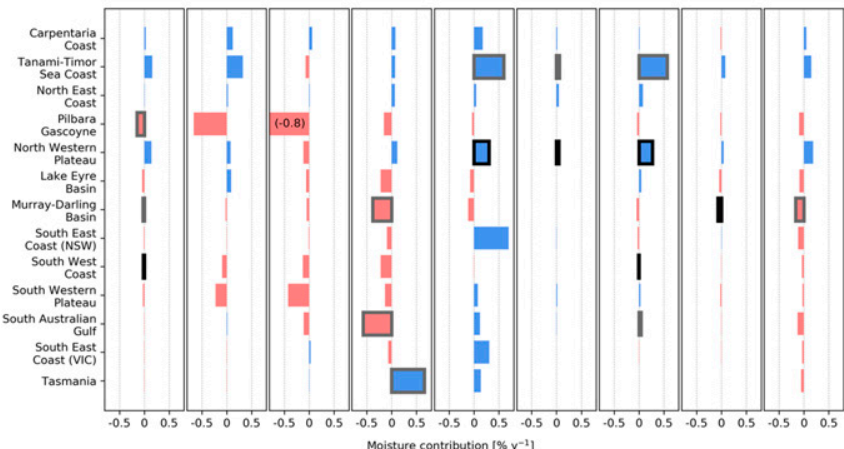

FIG. 8. Trends in seasonal moisture contribution $\left(\% \mathrm{yr}^{-1}\right)$. Values represent the change in moisture contributed by each source relative to the mean (1979-2013) total moisture received by each basin each season. Trends that are statistically significant at the $95 \%$ level are edged in thick black lines, and those that are significant at the $90 \%$ level are edged in thick gray lines. Positive trends are shown in blue; negative trends are shown in red. Note the different axis limits among seasons; values are provided in parentheses where the bar exceeds the axis limit.

averaged 2D Eulerian procedure using ERA-Interim over 1990-2009, and forward-tracked moisture from predefined ocean regions. These methodologies reflect major differences in approach, assumptions, and data that account for differences in the results. We note the higher spatial resolution of forcing used in our study allows for finer representation of precipitation, particularly in areas of high relief such as the mountainous region in southeastern Australia. Furthermore, in some cases the atmospheric and evaporation data used in previous studies was independent of the precipitation estimate, while our approach uses a self-consistent water cycle.

\section{SOURCES OF MOISTURE FOR SOUTHEAST AUSTRALIAN PRECIPITATION}

An interesting feature in the identified source regions relates to northwest cloud bands (NWCBs), which commonly extend from the tropics in the northwest to the extratropics in the southeast and have been linked to precipitation in southeast Australia (Bureau of Meteorology 2013). Our back-tracking approach finds no evidence that precipitation in southeast Australia relies on moisture from the northwest. For the MDB and South East
Coast (New South Wales and Victoria) basins, we found moisture is primarily sourced from the Tasman Sea.

The apparent disagreement with the possible role of NWCBs can be reconciled. Reid et al. (2019) shows that days with NWCBs are associated with a northwestsoutheast-oriented trough pattern, flanked by high pressure systems to the southwest and north-northeast. The anticyclone to the northeast advects warm, moist tropical air southward where it is lifted over the cooler and drier air in the region of the trough. The location of the southeast's key source region from our results, the Tasman Sea, supports this model. McIntosh et al. (2012) also supports this interpretation. They back-tracked a precipitation event in the Mallee region of southern Australia that appeared associated with a northwest to southeast band of clouds. They found moisture was sourced from the ocean to the northeast of Australia, not the northwest. As the air parcel traveled southward from the northeast it was forced to rise over colder air and subsequently condensed and contributed to precipitation. For the same region Brown et al. (2009) demonstrated that the moisture source, apparently to the west based on a snapshot of winds, was to the northeast when proper consideration was given to the time- 
dependent winds and parcel height. Overall, the NWCBs therefore set up the large-scale synoptic conditions that allow oceanic moisture from the Tasman Sea to be advected anticyclonically into the trough, to be subsequently lifted and precipitated in Australia's southeast. Thus, while the NWCBs are an expression of the moistureadvecting process, it is unlikely they are a major source of moisture for precipitation in the southeast.

\section{b. Terrestrial and marine contributions}

Our results show advected marine evaporation is relatively more important than terrestrial evapotranspiration as a source of moisture for precipitation across Australia. More than three-quarters of moisture supplying Australia's precipitation is derived from ocean sources throughout the year and can reach over $90 \%$ in some basins. While moisture for precipitation in different basins is sourced from different ocean regions, the Tasman Sea is the most important contributor of moisture for all but the western and northwestern basins, where the Indian and Southern Oceans are the most important sources.

While all regions of Australia are dominated by marine contribution, some regions are more reliant on terrestrial contributions than others. The northnorthwest basins rely on terrestrial moisture in summer and autumn for around one-quarter of their seasonal precipitation. Southeastern basins rely on terrestrial moisture for around $18 \%$ of their spring and summer precipitation and, like the rest of southern Australia, experience higher levels of interannual variability in terrestrial contribution compared to the north. Continentwide terrestrial contributions were around 6 times more variable than marine sources. Since the north-northwest and southeast regions receive more moisture from terrestrial evapotranspiration than others, these areas are most vulnerable to land-cover changes. Potential changes in land cover that lower evapotranspiration will lower the supply of moisture for precipitation (Pitman et al. 2004), especially in regions that rely on it including the North Western Plateau, Tanami-Timor Sea Coast, Carpentaria Coast, North East Coast, MDB, and Lake Eyre. In contrast, the South West Coast is particularly vulnerable to changes in SSTs and atmospheric circulation processes that bring moisture from its relatively small marine source region, which supplies more than $97 \%$ of moisture for precipitation in winter.

\section{c. Precipitation recycling}

From the source regions, we computed a long-term time series of precipitation recycling for each basin and for the continent. On average, $19 \%$ of precipitation was recycled to contribute to further annual precipitation over Australia. Recycling was greatest in spring and summer and lowest in winter. The seasonal cycle of recycling was evident in all basins, with slight differences in the timing of minima and maxima depending on location.

Land-atmosphere coupling, as measured by precipitation recycling, was strongest in northern and eastern Australia. In summer and autumn, coupling processes amplified available moisture to contribute to further precipitation most strongly in the Carpentaria Coast (average annual maximum of $8.8 \%$ ) and Tanami-Timor Sea Coast (average annual maximum of $11.4 \%$ ), semiarid North Western Plateau (average annual maximum of $8.6 \%$ ), and Pilbara-Gascoyne (average annual maximum of $7.3 \%$ ). Terrestrial processes amplified precipitation most strongly in spring and summer in the temperate MDB (average annual maximum of $9.2 \%$ ). Recycling appeared least important in southwestern regions, approaching $0 \%$ in winter. The southwestern basins of South West Coast, South Western Plateau, and South Australian Gulf were dominated by remote processes that advect marine moisture onshore each month.

Our estimates of precipitation recycling show a similar spatial pattern to previous recycling estimates. The spatial pattern of recycling-highest in the northnorthwest and southeast, and lowest in the southwest-is similar to van der Ent and Savenije (2011), van der Ent et al. (2010), and Dirmeyer et al. (2009). However, we estimate slightly lower recycling ratios. At a scale of $10^{5} \mathrm{~km}^{2}$, we estimate recycling to range from an annual average of approximately $1 \%$ in the southwest to $3.4 \%$ in the north-northwest (Fig. 7), as compared with previous estimates of approximately $<2 \%-8 \%$ (Dirmeyer and Brubaker 2007), <3\%-8\% (Dirmeyer et al. 2009), and $<1 \%-5 \%$ (van der Ent and Savenije 2011). Our range of estimates varied little $( \pm 0.1 \%)$ when we matched the time period to that of Dirmeyer and Brubaker (2007) and Dirmeyer et al. (2009), 1979-2003, or to van der Ent and Savenije (2011), 1999-2008. Moreover, the range of recycling estimated by previous studies fits within the interannual variability estimated here (Fig. 5). Differences in estimates were expected because of different forcing, resolution, and back-trajectory algorithms, as discussed in section 4 a.

The relatively low recycling ratios estimated in the present study echo the results of Hope and Watterson (2018), who found limited precipitation persistence across Australia following very wet months. While the analysis did not directly estimate recycling, it indicates that any recycling was limited and declined quickly after the precipitation events.

\section{d. Trends}

The positive summer and negative winter trends in moisture contributed to the MDB align with observed 
precipitation trends (Bureau of Meteorology 2020). No significant trends were found in the associated marine source region evaporation in this study. This suggests regional moisture contribution changes are not a direct result of changes to marine source region evaporation. Instead these changes may be due to shifts in atmospheric circulation patterns, local land-atmosphere coupling or precipitation-generating mechanisms, or a combination of factors. Indeed, a range of processes have been identified as partially explaining the observed seasonal precipitation changes in southeastern Australia. These include changes in the frequency of El Niño and La Niña events (Cai and Cowan 2008; Freund et al. 2019), the Indian Ocean dipole (Ummenhofer et al. 2009), an increasing influence of the northern dry season (Cai and Cowan 2013), and the upward trend in the southern annular mode (Nicholls 2010).

Long-term changes to regional moisture contribution can also point to potential drivers of MDB precipitation trends. Precipitation simulated by WRF showed a positive trend of $+1.3 \mathrm{~mm} \mathrm{yr}^{-1}(p<0.05)$ in summer, and $-0.9 \mathrm{~mm} \mathrm{yr}^{-1}(p \leq 0.15)$ in winter, similar to estimates by the Bureau of Meteorology (2010) using gauged precipitation observations for the same period $\left(+1.5\right.$ and $-0.6 \mathrm{~mm} \mathrm{yr}^{-1}$ in summer and winter, respectively). Of the positive summer trend, $52 \%$ $\left(+0.7 \mathrm{~mm} \mathrm{yr}^{-1} ; p<0.05\right)$ was associated with rising contributions in summer moisture from the Tasman Sea, and $22 \%\left(+0.3 \mathrm{~mm} \mathrm{yr}^{-1} ; p \leq 0.1\right)$ from the South Pacific Ocean. Of the negative winter trend, $36 \%$ $\left(-0.3 \mathrm{~mm} \mathrm{yr}^{-1} ; p \leq 0.1\right)$ was associated with declining contributions in moisture from the Southern Ocean, $16 \%\left(-0.15 \mathrm{~mm} \mathrm{yr}^{-1} ; p<0.1\right)$ from the nonlocal land and $7 \%\left(-0.06 \mathrm{~mm} \mathrm{yr}^{-1} ; p<0.05\right)$ from the local land surface. These results suggest that MDB precipitation is being affected by an increase in the easterly flow of moisture from the Tasman Sea in summer and by a reduction in both terrestrial moisture and the westerly flow of moisture from the Southern Ocean in winter.

We found an upward trend in marine contributions to the northwest of Australia, especially in spring. We also found a significant upward trend in terrestrial contribution, indicating a strengthening of land-atmosphere coupling in this region in spring. Precipitation in northwest Australia has exhibited an increasing trend of more than $30 \mathrm{~mm}$ decade $^{-1}$ since the 1950s (Holper 2011). The attribution of these changes remains uncertain, but our results showed that positive trends in the marine contribution align with positive trends in evaporation in the associated marine source regions. This suggests that intensified evaporation, particularly in the Maritime Continent, subtropical Indian Ocean, and tropical Pacific Ocean, may have led to increased moisture advection over northwest Australia, which may, in turn, have contributed to the increasing precipitation seen in this region since the 1950s.

Observed precipitation declines in the southwest since the 1960s are not supported by significant declining trends in moisture contribution in this study. Hope et al. (2010) reported a 17\% decline in May-July precipitation in southwest Australia between 1969 and 2007, with sharper declines in the 1990s. Declining precipitation in the region has been attributed to a reduction in the number of low pressure systems and increase in persistence of high pressure systems (Hope et al. 2006). While our results indicate negative trends in moisture contributed to the region in winter, these are either small or statistically insignificant.

\section{Conclusions}

Using a Lagrangian back-trajectory approach, we quantified the evaporative source regions and level of precipitation recycling for Australia and multiple hydrological basins. Presenting the seasonal climatology of the newly established multidecadal time series of source region and recycling, we identify the key marine and terrestrial regions that supply moisture for precipitation across Australia.

We showed, for the first time, that source regions varied markedly across the different hydrological basins within Australia. In the north, key sources included the tropical Indian and Pacific Oceans, the Maritime Continent, and evapotranspiration from the northern Australian land surface. In the southwest, terrestrial contributions were minimal, and moisture was supplied from a small source region within the Southern and subtropical Indian Oceans. The key source regions for the southeast were the Tasman Sea and Southern Ocean, with secondary contributions from terrestrial sources. While the Tasman Sea and the Southern Ocean were the most important source regions for precipitation in the south and east of Australia, they were also the ocean regions to exhibit the greatest interannual variability. Interannual variability of ocean sources was much less than terrestrial sources, whose year-to-year variability was 6 times greater than marine sources on average.

We have shown that advected marine evaporation dominated the moisture contributed to precipitation across Australia in all seasons, compared to terrestrial evapotranspiration. While marine advection was relatively more important, some regions were more reliant on terrestrial contributions than others. Precipitation in the north-northwest and southeast relied on terrestrial moisture for up to one-quarter of its seasonal precipitation. Precipitation in the north-northwest and southeast is therefore most vulnerable to land-cover 
changes that may potentially alter the amount of evapotranspiration, and thus the terrestrial moisture available for local precipitation. In contrast, precipitation in the southwest was dominated by remote processes as it received the majority of its moisture from a relatively small ocean region, making it vulnerable to atmospheric circulation changes that advect the moisture necessary for precipitation in this region.

The level of recycling of terrestrial moisture and the strength of land-atmosphere coupling varied across Australia. On average 19\% of moisture was recycled across Australia to contribute to further precipitation each year. Recycling was strongest in northern and eastern Australia in spring and summer $(\sim 9 \%)$, and weakest in the southwest in winter. Winter land-atmosphere coupling strength declined in the MDB over the last 35 years, as demonstrated by the downward trend in precipitation recycling in this region. In contrast coupling strength in the northwestern basins increased, particularly in spring.

Moisture contributed by different ocean regions showed distinct changes over the study period. Summer moisture from the South Pacific Ocean and the Tasman Sea showed positive trends for most basins. The MDB in particular showed positive trends in marine and terrestrial contributions in spring and summer and negative trends in autumn and winter, in line with observed precipitation trends. Furthermore, we found a positive trend in both terrestrial and marine contributions to the northwest of Australia, especially in spring, which is also in line with observed trends in precipitation.

The relative importance of local and remote processes and strength of coupling processes presented here represent the average or climatological condition. A next step is to analyze the relative roles of marine advection versus local recycling during the various stages of drought development. This is particularly relevant in the MDB, a region that has suffered extreme droughts in recent years and where land-atmosphere coupling strength appears relatively strong. Insight into landatmosphere coupling behavior during drought onset, duration, and termination will help guide our understanding of climate processes and aid the model developments needed to improve the prediction of this region's precipitation and its extremes. However, there are other regions of Australia where the variability or trend in precipitation is impacting natural and human systems. The dataset that forms the basis of this study provides a foundation for future analysis of precipitation in each part of Australia and can be used to explore, for example, the origin of drought-breaking events, the origin of the most intense events, or the role of large-scale drivers in source region variability.
Acknowledgments. This work was made possible by an Australian National University Australian Government Research Training Scholarship for author Holgate and support from the ARC Centre of Excellence for Climate System Science (CE110001028). Holgate and author van Dijk were supported through the ARC Discovery Projects funding scheme (project DP40103679). Authors Evans and Pitman were supported through the ARC Centre of Excellence for Climate Extremes (CE170100023). The authors thank the NCI and its staff for computational support and Jessica Keune and two anonymous reviewers for their constructive feedback. CORDEX-Australasia climate simulations are publicly available online (https:// climatechange.environment.nsw.gov.au/Climate-projectionsfor-NSW/About-NARCliM).

\section{REFERENCES}

Brown, J. N., P. C. McIntosh, M. J. Pook, and J. S. Risbey, 2009: An investigation of the links between ENSO flavors and rainfall processes in southeastern Australia. Mon. Wea. Rev., 137, 3786-3795, https://doi.org/10.1175/2009MWR3066.1.

Brubaker, K. L., D. Entekhabi, and P. S. Eagleson, 1993: Estimation of continental precipitation recycling. J. Climate, 6, 1077-1089, https:// doi.org/10.1175/1520-0442(1993)006,1077:EOCPR.2.0.CO;2.

Bureau of Meteorology, 2010: Australian climate averages-Rainfall (climatology 1961-1990). Burau of Meteorology, accessed 17 October 2019, http://www.bom.gov.au/jsp/ncc/climate_averages/ rainfall/index.jsp.

_ 2012: Australian Hydrological Geospatial Fabric (Geofabric). Bureau of Meteorology, accessed 18 October 2019, http:// www.bom.gov.au/water/about/riverBasinAuxNav.shtml.

_- 2013: About Australian climate. Bureau of Meteorology, accessed 28 November 2019, http://www.bom.gov.au/climate/ about/?bookmark = nwcloudband.

_ 2020 : Climate change and variability: Tracker: Australian timeseries graphs. Bureau of Meteorology, accessed 11 May 2020, http://www.bom.gov.au/climate/change/index.shtml\#tabs= Tracker\&tracker $=$ timeseries \& $\mathrm{tQ}=$ graph $\% 3$ Drain $\% 26$ area $\%$ 3Dmdb\%26season\%3D0608\%26ave_yr\%3DT.

Cai, W., and T. Cowan, 2008: Dynamics of late autumn rainfall reduction over southeastern Australia. Geophys. Res. Lett., 35, L09708, https://doi.org/10.1029/2008GL033727.

— and - 2013: Southeast Australia autumn rainfall reduction: A climate-change-induced poleward shift of oceanatmosphere circulation. J. Climate, 26, 189-205, https://doi.org/ 10.1175/JCLI-D-12-00035.1.

Cortés-Hernández, V. E., F. Zheng, J. Evans, M. Lambert, A. Sharma, and S. Westra, 2016: Evaluating regional climate models for simulating sub-daily rainfall extremes. Climate Dyn., 47, 1613-1628, https://doi.org/10.1007/s00382-015-2923-4.

Dirmeyer, P. A., and K. L. Brubaker, 1999: Contrasting evaporative moisture sources during the drought of 1988 and the flood of 1993. J. Geophys. Res., 104, 19383-19397, https://doi.org/ 10.1029/1999JD900222.

, and _ 2007: Characterization of the global hydrologic cycle from a back-trajectory analysis of atmospheric water vapor. J. Hydrometeor., 8, 20-37, https://doi.org/10.1175/JHM557.1. 
- — — - and T. DelSole, 2009: Import and export of atmospheric water vapor between nations. J. Hydrol., 365, 11-22, https:// doi.org/10.1016/j.jhydrol.2008.11.016.

— J. Wei, M. G. Bosilovich, and D. M. Mocko, 2014: Comparing evaporative sources of terrestrial precipitation and their extremes in MERRA using relative entropy. J. Hydrometeor., 15, 102-116, https://doi.org/10.1175/JHM-D-13-053.1.

Di Virgilio, G., and Coauthors, 2019: Evaluating reanalysis-driven CORDEX regional climate models over Australia: Model performance and errors. Climate Dyn., 53, 2985-3005, https:// doi.org/10.1007/s00382-019-04672-w.

Eltahir, E. A. B., and R. L. Bras, 1996: Precipitation recycling. Rev. Geophys., 34, 367-378, https://doi.org/10.1029/96RG01927.

Evans, J. P., A. J. Pitman, and F. T. Cruz, 2011: Coupled atmospheric and land surface dynamics over southeast Australia: A review, analysis and identification of future research priorities. Int. J. Climatol., 31, 1758-1772, https://doi.org/10.1002/joc.2206.

_ , F. Ji, G. Abramowitz, and M. Ekström, 2013: Optimally choosing small ensemble members to produce robust climate simulations. Environ. Res. Lett., 8, 044050, https://doi.org/ 10.1088/1748-9326/8/4/044050.

—, D. Argueso, R. Olson, and A. Di Luca, 2017: Bias-corrected regional climate projections of extreme rainfall in south-east Australia. Theor. Appl. Climatol., 130, 1085-1098, https:// doi.org/10.1007/s00704-016-1949-9.

Fita, L., J. P. Evans, D. Argüeso, A. King, and Y. Liu, 2017: Evaluation of the regional climate response in Australia to large-scale climate modes in the historical NARCliM simulations. Climate Dyn., 49, 2815-2829, https://doi.org/10.1007/ s00382-016-3484-x.

Freund, M. B., B. J. Henley, D. J. Karoly, H. V. McGregor, N. J. Abram, and D. Dommenget, 2019: Higher frequency of central Pacific El Niño events in recent decades relative to past centuries. Nat. Geosci., 12, 450-455, https://doi.org/10.1038/ s41561-019-0353-3.

Gimeno, L., and Coauthors, 2012: Oceanic and terrestrial sources of continental precipitation. Rev. Geophys., 50, RG4003, https://doi.org/10.1029/2012RG000389.

Goessling, H. F., and C. H. Reick, 2013: On the "well-mixed" assumption and numerical 2-D tracing of atmospheric moisture. Atmos. Chem. Phys., 13, 5567-5585, https://doi.org/10.5194/ acp-13-5567-2013.

Hobeichi, S., G. Abramowitz, J. Evans, and A. Ukkola, 2018: Derived Optimal Linear Combination Evapotranspiration (DOLCE): A global gridded synthesis ET estimate. Hydrol. Earth Syst. Sci., 22, 1317-1336, https://doi.org/10.5194/hess-22-1317-2018.

$\ldots$ - — , and — 2020: Derived Optimal Linear Combi nation Evapotranspiration-DOLCE v2.0. Research Data Australia, accessed 14 May 2020, https://doi.org/10.25914/ 5eab8f533aeae.

Holper, P. N., 2011: Australian rainfall-Past, present and future. CSIRO and the Bureau of Meteorology Paper, 18 pp., accessed 15 October 2019, https:/www.cawcr.gov.au/projects/Climatechange/ wp-content/uploads/2016/11/rainfall-paper.pdf.

Hope, P. K., and I. Watterson, 2018: Persistence of cool conditions after heavy rain in Australia. J. South. Hemisphere Earth Syst. Sci., 68, 41-64, https://doi.org/10.22499/3.6801.004.

_ W. Drosdowsky, and N. Nicholls, 2006: Shifts in the synoptic systems influencing southwest Western Australia. Climate Dyn., 26, 751-764, https://doi.org/10.1007/s00382-006-0115-y.

- B. Timbal, and R. Fawcett, 2010: Associations between rainfall variability in the southwest and southeast of Australia and their evolution through time. Int. J. Climatol., 30, 13601371, https://doi.org/10.1002/joc.1964.

Jones, D. A., W. Wang, and R. Fawcett, 2009: High-quality spatial climate data-sets for Australia. Aust. Meteor. Oceanogr. $J .$, 58, 233-248, https://doi.org/10.22499/2.5804.003.

McIntosh, P. C., J. S. Risbey, J. N. Brown, and M. J. Pook, 2012: Apparent and real sources of rainfall associated with a cutoff low in southeast Australia. CAWCR Research Letters, No. 8, The Centre for Australian Weather and Climate Research, Melbourne, Australia, 4-9, https://www.cawcr.gov.au/researchletters/ CAWCR_Research_Letters_8.pdf.

Merrill, J. T., R. Bleck, and D. Boudra, 1986: Techniques of Lagrangian trajectory analysis in isentropic coordinates. Mon. Wea. Rev., 114, 571-581, https://doi.org/10.1175/1520-0493(1986) 114<0571:TOLTAI $>2.0 . \mathrm{CO} ; 2$

Miralles, D. G., and Coauthors, 2016: Contribution of waterlimited ecoregions to their own supply of rainfall. Environ. Res. Lett., 11, 124007, https://doi.org/10.1088/1748-9326/11/12/ 124007.

Nicholls, N., 2010: Local and remote causes of the southern Australian autumn-winter rainfall decline, 1958-2007. Climate Dyn., 34, 835-845, https://doi.org/10.1007/s00382-009-0527-6.

Olson, R., J. Evans, A. Di Luca, and D. Argüeso, 2016: The NARCliM project: Model agreement and significance of climate projections. Climate Res., 69, 209-227, https://doi.org/ $10.3354 / \mathrm{cr} 01403$.

Pitman, A. J., G. T. Narisma, R. A. Pielke, and N. J. Holbrook, 2004: Impact of land cover change on the climate of southwest Western Australia. J. Geophys. Res., 109, D18109, https:// doi.org/10.1029/2003JD004347.

Reid, K. J., I. Simmonds, C. L. Vincent, and A. D. King, 2019: The Australian northwest cloudband: Climatology, mechanisms, and association with precipitation. J. Climate, 32, 6665-6684, https://doi.org/10.1175/JCLI-D-19-0031.1.

Sharmila, S., and H. H. Hendon, 2020: Mechanisms of multiyear variations of Northern Australia wet-season rainfall. Sci. Rep., 10, 5086, https://doi.org/10.1038/s41598-020-61482-5.

Stohl, A., and P. James, 2005: A Lagrangian analysis of the atmospheric branch of the global water cycle. Part II: Moisture transports between Earth's ocean basins and river catchments. J. Hydrometeor., 6, 961-984, https://doi.org/10.1175/JHM470.1.

Ummenhofer, C. C., M. H. England, P. C. McIntosh, G. A. Meyers, M. J. Pook, J. S. Risbey, A. S. Gupta, and A. S. Taschetto, 2009: What causes southeast Australia's worst droughts? Geophys. Res. Lett., 36, L04706, https://doi.org/10.1029/2008GL036801.

van der Ent, R. J., and H. H. G. Savenije, 2011: Length and time scales of atmospheric moisture recycling. Atmos. Chem. Phys., 11, 1853-1863, https://doi.org/10.5194/acp-11-1853-2011.

, and - 2013: Oceanic sources of continental precipitation and the correlation with sea surface temperature. Water Resour. Res., 49, 3993-4004, https://doi.org/10.1002/wrcr.20296.

,,-- B. Schaefli, and S. C. Steele-Dunne, 2010: Origin and fate of atmospheric moisture over continents. Water Resour. Res., 46, W09525, https://doi.org/10.1029/2010WR009127.

Yu, L., 2007: Global variations in oceanic evaporation (1958-2005): The role of the changing wind speed. J. Climate, 20, 5376-5390, https://doi.org/10.1175/2007JCLI1714.1.

Zhang, J., W.-C. Wang, and J. Wei, 2008: Assessing land-atmosphere coupling using soil moisture from the global land data assimilation system and observational precipitation. J. Geophys. Res., 113, D17119, https://doi.org/10.1029/2008JD009807. 